\title{
IMPERIAL TOBACCO AND TRIAL LAWYERS: AN UNSTABLE AND UNSUCCESSFUL RETREAT
}

\author{
(ALYN) JAMES JOHNSON ${ }^{*}$
}

\begin{abstract}
The Supreme Court of Canada established an architectural model of the Constitution through the Reference re Remuneration of Judges of the Provincial Court of Prince Edward Island and the Reference re Secession of Quebec. This model has an informing core of "organizing principles" engaging both written and unwritten rules. These two decisions and earlier landmark rulings have used unwritten principles to reach dramatic conclusions. Yet, the Supreme Court departs from this line of authority in Imperial Tobacco in which a strong textual approach is taken. The author argues this decision led to instability in constitutional doctrine that was further complicated in Trial Lawyers. This article explores the strengths of the Judges Reference and the Secession Reference and the need to uphold the use of unwritten constitutional principles while calling for the Imperial Tobacco case to be set aside.
\end{abstract}

\section{TABLE OF CONTENTS}

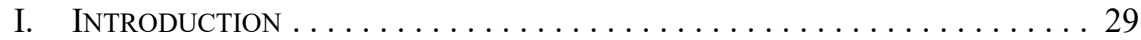

II. IMPERIAL TOBACCO AND THE PRIORITIZATION OF TEXT . . . . . . . . 32

A. NARrowing the AMbit of the Rule of LAW . . . . . . . . . 34

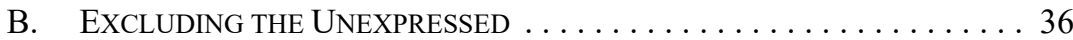

C. "NeCESSARY IMPLiCATION": A TEXTUAL THRESHOLD . . . . . . . . 37

III. TRIAL LAWYERS: RENDERING TEXT "AMORPHOUS" . . . . . . . . . . . . 41

A. SECTION 96 Doctrine AND THE "BASIC JUdicial

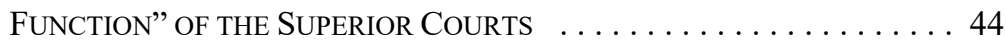

B. The Simplicity of the Rule of LaW AnALysis . . . . . . . . . 47

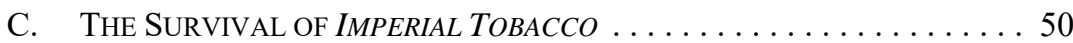

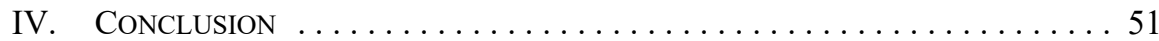

\section{INTRODUCTION}

In Reference re Remuneration of Judges of the Provincial Court of Prince Edward Island; Reference re Independence and Impartiality of Judges of the Provincial Court of Prince Edward Island ${ }^{1}$ and Reference re Secession of Quebec, ${ }^{2}$ the Supreme Court of Canada outlines an architectural model of the Constitution. This model consists of an informing core of foundational "organizing principles," and both written and unwritten rules emanating from the core. ${ }^{3}$ The foundation supports the rules; the rules build on and realize the implications of the foundation. While texts "have a primary place in determining constitutional rules, they are not exhaustive." The Constitution "embraces unwritten, as well as written rules," and

PhD in Law (Queen's University); PhD in English Literature (Queen's University); LLB (University of Alberta). Prior to his recent doctoral work in law, James worked for six years as an Associate at Norton Rose Canada LLP in Toronto, and he taught English literature at the university level for five years. Comments are welcome at j.johnson@queensu.ca.

[1997] 3 SCR 3 [Judges Reference].

[1998] 2 SCR 217 [Secession Reference].

Judges Reference, supra note 1 at paras 83,95, 108, and generally at paras 83-109; Secession Reference, ibid at paras 32, 49-54.

$4 \quad$ Secession Reference, ibid at para 32. 
"contain[s] a comprehensive set of rules and principles which are capable of providing an exhaustive legal framework for our system of government." In these two landmark rulings, as well as earlier decisions such as Reference re Manitoba Language Rights; ${ }^{6}$ New Brunswick Broadcasting Co. v. Nova Scotia (Speaker of the House of Assembly); ${ }^{7}$ and MacMillan Bloedel Ltd. v. Simpson, ${ }^{8}$ the Supreme Court employs unwritten principles, and unwritten rules derived from these principles, to reach dramatic conclusions including halting the operation of constitutional texts, overruling legislation, and imposing obligations on both the federal and provincial governments. ${ }^{9}$

Subsequent judgments have never expressly rejected the theory of the Constitution outlined in the Judges Reference and the Secession Reference. Indeed, in the 2014 Reference re Senate Reform, the Supreme Court endorsed its earlier unwritten principles decisions, and their theoretical implications, in the strongest possible terms. ${ }^{10}$ Nevertheless, a dissonant chord is struck in 2005 by British Columbia v. Imperial Tobacco Canada Ltd. ${ }^{11}$ Here the Supreme Court prioritizes text - constitutional and legislative - in a manner that is at odds with the larger controlling framework outlined in the architectural model.

While decided in 2005, Imperial Tobacco has roots leading back to $1998,{ }^{12}$ and thus is arguably part of a spike in constitutional litigation following in the wake of the Judges Reference and the Secession Reference. ${ }^{13}$ But if Imperial Tobacco was an attempt to stem the use of unwritten principles, it did so at the price of theoretical and doctrinal coherence. A preferable approach can be found in the 2002 decision of Babcock v. Canada (Attorney General), in which the Supreme Court rejects an unwritten principles challenge to legislation by stating that the principles in question (the rule of law, judicial independence, and the separation of powers) could not overrule the unwritten principle of parliamentary sovereignty "in this case."14 Babcock manages to remind litigants of the central place of legislatures and legislation in a democratic system, even while affirming the architectural approach to the Constitution outlined in the Judges Reference and the Secession Reference. ${ }^{15}$ Imperial Tobacco's textualism, on the other hand, upsets the earlier authorities, and has rendered their application uncertain.

Judges Reference, supra note 1 at para 92; Secession Reference, ibid.

[1985] 1 SCR 721 [Manitoba Language Reference].

[1993] 1 SCR 319 [New Brunswick Broadcasting].

[1995] 4 SCR 725 [MacMillan Bloedel].

For a detailed discussion of these decisions, and their relationship to the Supreme Court's architectural model of the Constitution, see (Alyn) James Johnson, "The Judges Reference and the Secession Reference at Twenty: Reassessing the Supreme Court of Canada's Unfinished Unwritten Constitutional Principles Project" (2019) 56:4 Alta L Rev 1077.

2014 SCC 32 at paras 23-26, and especially para 26 [Senate Reference].

2005 SCC 49 [Imperial Tobacco].

See HMTQ v Imperial Tobacco Canada Limited, 2003 BCSC 877 at paras 6-9; JTI-Macdonald v AG$B C, 2000$ BCSC 312 at para 8.

13 On the increase in constitutional litigation in the years immediately following the Secession Reference, see Warren J Newman, “Grand Entrance Hall,' Back Door or Foundation Stone? The Role of Constitutional Principles in Construing and Applying the Constitution of Canada" (2001) 14 SCLR 197 at 198-99; Jean Leclair, "Canada's Unfathomable Unwritten Constitutional Principles" (2002) 27:2 Queen's LJ 389 at 396-97, 408-409.

$14 \quad 2002$ SCC 57 at paras 54-55 [Babcock].

Babcock warns that "[i]t is well within the power of the legislature to enact laws, even laws which some would consider draconian, as long as it does not fundamentally alter or interfere with the relationship between the courts and the other branches of government" (ibid at para 57). 
Imperial Tobacco's textualist agenda can be seen in part through limitations placed on the ambit of the rule of law, which, the Supreme Court strongly suggests, is unlikely to provide the basis for a challenge to legislation. This proposition does not sit well with the Manitoba Language Reference, MacMillan Bloedel, the Judges Reference, and the Secession Reference, all of which affirm the central importance of the rule of law to the structure of the Canadian Constitution. Imperial Tobacco's textualism is also evident in certain demands placed on the process of constitutional interpretation. Most important here is the suggestion that unwritten principles must be sourced in the "express terms" of the text of the Constitution before they can form the basis of an argument to overrule legislation. ${ }^{16}$ This methodological demand, with respect, is inconsistent with the earlier authorities, and inconsistent with the architectural model. Requiring challenges to legislation to be negotiated by constitutional text creates instability by placing too much weight on only one part of the overall constitutional edifice. Circumstances can arise, and have arisen in the judgments enumerated above, where threats to the structure of the Constitution cannot be answered by text and instead require a pragmatic analysis drawing directly on unwritten sources of authority. ${ }^{17}$ A structural threat challenges the web of institutional relationships that governs the distribution of state power and the processes through which laws are generated, interpreted, and applied. To answer such a fundamental threat, it is necessary to turn to the organizing principles of the Constitution. The ultimate solution to the threat may lead through text, unwritten rules, or a combination of the two.

In this article, I argue that the instability of Imperial Tobacco's textualist retreat from unwritten principles is best viewed through the 2014 decision of Trial Lawyers Association of British Columbia v. British Columbia (Attorney General). ${ }^{18}$ Trial Lawyers presents a structural threat (government action impairing access to justice) that demands an unwritten principles analysis. The Supreme Court appears to recognize the appropriateness of such a response and employs the rule of law to achieve a clear and compelling solution. However, in order to maintain doctrinal continuity with Imperial Tobacco (continuity threatened by the very use of the rule of law), the Supreme Court awkwardly forces the analysis to navigate the above-noted methodological requirement. The result is unstable: text, which should promote legal certainty, fails to do so. The unwritten principles argument based on the rule of law remains standing, but is surrounded by vague invocations of written authority. The textualist project of Imperial Tobacco essentially collapses in Trial Lawyers.

I consider the Imperial Tobacco retreat into text in Part II and the Trial Lawyers collapse in Part III. 


\section{Imperial Tobacco AND the Prioritization of TeXt}

In the late 1990s, British Columbia enacted legislation that created a cause of action against tobacco manufacturers in order to recover health care costs associated with treating tobacco-related diseases. In Imperial Tobacco, various of the manufacturers alleged that the legislation violated the rule of law and judicial independence by unfairly targeting specific entities, by being retroactive rather than prospective in character, and by altering the evidentiary and burden of proof norms of traditional tort law. These unwritten principles claims were all unsuccessful. Justice Major, in the course of his opinion for the unanimous Supreme Court of Canada, observed that

the appellants' arguments fail to recognize that in a constitutional democracy such as ours, protection from legislation that some might view as unjust or unfair properly lies not in the amorphous underlying principles of our Constitution, but in its text and the ballot box. ${ }^{19}$

There is little doubt that the content of legislation — its fairness and justness — is primarily monitored through democratic elections and through the norms entrenched in the text of the Constitution, especially the Canadian Charter of Rights and Freedoms. ${ }^{20}$ Nevertheless, these comments reveal a dismissive approach to unwritten principles that is hard to reconcile with the Judges Reference, where "organizing principles" are "the very source of the substantive provisions" of the Constitution, ${ }^{21}$ and the Secession Reference, where "underlying principles" are "vital unstated assumptions" that "dictate major elements of the architecture of the Constitution itself and are as such its lifeblood." 22 The Secession Reference also provides that

$[u]$ nderlying constitutional principles may in certain circumstances give rise to substantive legal obligations (have 'full legal force,' as we described it in the Patriation Reference ...), which constitute substantive limitations upon government action. ${ }^{23}$

Contrary to Justice Major's assertion, this passage states that unwritten principles can have "full legal force," and thereby overrule legislation, despite its democratic pedigree. ${ }^{24}$

While the preceding paragraph addresses the incongruity between Imperial Tobacco's dismissive approach to unwritten principles and statements made by the Supreme Court in earlier decisions, an even more pressing incongruity comes into focus when the phrase "amorphous underlying principles" is set against what the Supreme Court actually does in its earlier precedents. There is nothing "amorphous" about the legal rules used to halt the

Imperial Tobacco, supra note 11 at para 66.

Part I of the Constitution Act, 1982, being Schedule B to the Canada Act 1982 (UK), 1982, c 11 [Charter].

Supra note 1 at para 95.

Supra note 2 at paras 49,51 .

Ibid at para 54 [citation omitted].

In Reference re Resolution to Amend the Constitution, [1981] 1 SCR 753 at 844-45, Justices Martland and Ritchie, speaking of "judicially developed legal principles and doctrines," stressed that "they have been accorded full legal force in the sense of being employed to strike down legislative enactments." While delivered in dissent, these comments are expressly adopted by the entire Supreme Court in the above passage from the Secession Reference ("as we described it"). The unanimous Supreme Court also endorses the comments of Justices Martland and Ritchie in the Manitoba Language Reference, supra note 6 at 752 . 
operation of constitutional texts in the Manitoba Language Reference ${ }^{25}$ or New Brunswick Broadcasting. ${ }^{26}$ Nor is there anything "amorphous" about the three legal rules applied in the Judges Reference to protect the courts from "intrusions" from the legislative and executive branches of government. ${ }^{27}$ These concrete yet unwritten legal rules are all examples of what the Supreme Court refers to as "structural imperatives" in OPSEU v. Ontario (Attorney General). ${ }^{28}$ In that decision, the abstract principle of representative democracy leads to the recognition of the concrete "structural imperative" that "neither Parliament nor the provincial legislatures may enact legislation the effect of which would be to substantially interfere with" free political speech. ${ }^{29}$

Imperial Tobacco's reference to "amorphous underlying principles" is ultimately reductive, for this phrase does not acknowledge that the Supreme Court's methodology in the above decisions is to extract concrete legal rules from abstract principles. The problem with the appellants' arguments in Imperial Tobacco was not the use of unwritten principles per se, but rather the failure to generate concrete rules from these principles. That failure does not in any way impugn unwritten principles, their profound status in the Canadian Constitution, or the methodology that the Supreme Court employs in prior decisions. None of the rule of law or judicial independence claims made by the appellants in Imperial Tobacco appear to give rise to concrete rules ("structural imperatives") that should have legal force. The rule of law, for example, may well, on some accounts, contain the propositions that laws should be general in character and should not be retroactive. ${ }^{30}$ But the general theoretical content of the rule of law is not synonymous with its constitutional ramifications in any particular legal system. The earlier judgments noted above, from the 1985 Manitoba Language Reference to the 1998 Secession Reference, provide that a cogent argument outlining the structural significance of the alleged attributes of an unwritten principle must be in place before such a principle can be given legal effect by a court. Adopting Justice

The combined effect of section 23 of the Manitoba Act, 1870, 33 Vict, c 3 and section 52 of the Constitution Act, 1982, being Schedule B to the Canada Act 1982 (UK), 1982, c 11, led to the conclusion that virtually all of the enacted laws in the Province of Manitoba were illegal. In response to this crisis, the Supreme Court recognized a concrete rule, derived from the abstract principle of the rule of law, requiring the "creation and maintenance of an actual order of positive laws which preserves and embodies the more general principle of normative order" (Manitoba Language Reference, supra note 6 at 749). This rule was used to halt the commands of the constitutional texts until the province could respond to the legislative void (ibid at 758).

26 Pursuant to the principle of parliamentary privilege, sourced in part in the abstract principle of representative democracy, the Supreme Court found that the Nova Scotia House of Assembly must have the power to control its internal processes and must not be subject to interference arising from Charter claims (New Brunswick Broadcasting, supra note 7 at 385-93, and especially 387-89).

27 The three rules, or "objective guarantees against intrusions," which were found to "inhere" in the principle of the separation of powers, provide that reductions or freezes in judicial salaries must flow from a "special process" that is "independent, effective, and objective"; that members of the judiciary cannot engage in any negotiations on matters of remuneration; and that judicial salaries cannot fall below a certain minimum level (Judges Reference, supra note 1 at paras 138, 146, and 133-35). [1987] 2 SCR 2 at 57 [OPSEU].

Ibid at 57. While this statement was obiter, it was expressly reaffirmed, along with the process of deriving "structural imperatives" from unwritten principles, in the Judges Reference, supra note 1 at paras $103,108$.

30 See Lon L Fuller, The Morality of Law, revised ed (New Haven: Yale University Press, 1969) at 46-49, 51-62, 210. While Fuller argues that some respect for the propositions of generality and prospectivity is essential for the existence of a legal order, he stops short of demanding total adherence (ibid at 41-42). For theorists who have wrestled with competing considerations relating to the rule of law requirements of generality and prospectivity, see William E Scheuerman, Between the Norm and the Exception: The Frankfurt School and the Rule of Law (Cambridge, Mass: MIT Press, 1994) at 68-80, 93-95, 211-17; TRS Allan, Constitutional Justice: A Liberal Theory of the Rule of Law (New York: Oxford University Press, 2001) at 36-40, 50, 53, 56-59, 250-57. 
Major's pejorative language, the earlier decisions provide that an "amorphous" principle must be made concrete in the context of a tangible constitutional threat in order for legal results to follow, particularly results as dramatic as overruling legislation. In Imperial Tobacco, the appellants did not demonstrate a clear threat to the Constitution, only legislation potentially costing them billions of dollars. The failure to sufficiently concretize claims in relation to the architecture of the Constitution adequately accounts for the result in that case. There was no need for the Supreme Court to do anything other than recognize this point, and certainly no need to make statements undermining a sophisticated theory (the architectural model) and a rich body of prior decisions.

Imperial Tobacco's privileging of text over unwritten principles goes beyond the passage quoted above. Under separate headings below, I consider Justice Major's use of a strategy of statutory interpretation that has the practical effect of rendering written constitutional statements exclusive, and also his methodological requirement that unwritten rules and principles must pass a textual threshold before they can be used to challenge legislation. First, however, I consider the institutional limitations placed on the ambit of the rule of law. My focus under each heading is Imperial Tobacco's departure from earlier unwritten principles decisions in which texts (legislative and constitutional) are placed within a larger structural framework.

\section{A. NARrowing The AMbit OF THE RULE OF LAW}

Imperial Tobacco's retreat from prior authorities is particularly pronounced in the strong suggestion that the rule of law cannot be used to overrule legislation:

This Court has described the rule of law as embracing three principles. The first recognizes that "the law is supreme over officials of the government as well as private individuals, and thereby preclusive of the influence of arbitrary power": Manitoba Language Rights.... The second "requires the creation and maintenance of an actual order of positive laws which preserves and embodies the more general principle of normative order": Manitoba Language Rights... The third requires that "the relationship between the state and the individual ... be regulated by law": Reference re Secession of Quebec....

So understood, it is difficult to conceive of how the rule of law could be used as a basis for invalidating legislation such as the Act based on its content. That is because none of the principles that the rule of law embraces speak directly to the terms of legislation.

This does not mean that the rule of law as described by this Court has no normative force. As McLachlin C.J. stated in Babcock, "unwritten constitutional principles," including the rule of law, "are capable of limiting government actions." See also Reference re Secession of Quebec.... But the government action constrained by the rule of law as understood in Manitoba Language Rights and Reference re Secession of Quebec is, by definition, usually that of the executive and judicial branches. Actions of the legislative branch are constrained too, but only in the sense that they must comply with legislated requirements as to manner and form (i.e., the procedures by which legislation is to be enacted, amended and repealed). ${ }^{31}$ 
These comments are surprising. The rule of law plays a determinative role in each of the Manitoba Language Reference, MacMillan Bloedel, and the Secession Reference, and is an important governing principle in the Judges Reference. None of these decisions imply limitations on this fundamental constitutional principle, and the three attributes of the rule of law noted by Justice Major are not presented as being exhaustive. The claim that "none of the principles that the rule of law embraces speak directly to the terms of legislation," with respect, appears to overlook the very real possibility that the "content" of legislation can authorize executive officials to act in an arbitrary manner (contrary to the first attribute), ${ }^{32}$ and can be so vague as to undermine the legal relationship between the individual and the state (contrary to the third attribute). ${ }^{33}$

An even more pressing objection to Justice Major's discussion, however, is that the Supreme Court itself has surely used the rule of law against legislation threatening the structure of the Constitution on several occasions. Most notably, MacMillan Bloedel overrules a provision in a federal statute threatening the "core jurisdiction" of the superior courts:

\begin{abstract}
Governance by rule of law requires a judicial system that can ensure its orders are enforced and its process respected. In Canada, the provincial superior court is the only court of general jurisdiction and as such is the centre of the judicial system. None of our statutory courts has the same core jurisdiction as the superior court and therefore none is as crucial to the rule of law. To remove the power to punish contempt ex facie by youths would maim the institution which is at the heart of our judicial system. Destroying part of the core jurisdiction would be tantamount to abolishing the superior courts of general jurisdiction, which is impermissible without constitutional amendment.
\end{abstract}

The core jurisdiction of the provincial superior courts comprises those powers which are essential to the administration of justice and the maintenance of the rule of law. It is unnecessary in this case to enumerate the precise powers which compose inherent jurisdiction, as the power to punish for contempt ex facie is obviously within that jurisdiction. ${ }^{34}$

Chief Justice Lamer, who wrote the majority opinion, underlines the primary importance of the rule of law to the decision in a scholarly article written shortly thereafter:

It is important to note that, while s. 96 was integral to the Court's ruling on the validity of the grant of jurisdiction to the youth courts over contempt ex facie by young offenders, it played no direct role in the ruling on the validity of the removal of that same jurisdiction from the superior courts. That ruling, as the

In $R v$ Morgentaler, [1988] 1 SCR 30 at 68-76, Chief Justice Dickson and Justice Lamer found that the content of legislation authorized arbitrary state conduct. My point is not that the rule of law could or should have given the Supreme Court adequate warrant to overrule the impugned legislation in this decision, but rather that the content of legislation can indeed violate "the principles that the rule of law embraces."

33 The "vagueness doctrine" under the Charter, which provides a basis on which to overrule legislation, is grounded on the rule of law: see $R v$ Nova Scotia Pharmaceutical Society, [1992] 2 SCR 606 at 640-43; Marc Ribeiro, Limiting Arbitrary Power: The Vagueness Doctrine in Canadian Constitutional Law (Vancouver: UBC Press, 2004) at 80-86. Again, my point here is not that the rule of law could or should provide an adequate warrant to overrule vague legislation outside of the Charter, but rather the narrower claim that the content of legislation can violate this unwritten principle, contrary to Justice Major's assertion. I note, however, that Ribeiro draws on the rule of law to argue that the vagueness doctrine should be extended beyond the Charter (ibid at 144-55). Supra note 8 at paras $37-38$. 
passage just quoted makes clear, derives from the rule of law itself and the special role played by the superior courts of general jurisdiction in preserving it. ${ }^{35}$

Two other decisions of note are the Judges Reference and the 2002 decision of Mackin $v$. New Brunswick (Minister of Finance); Rice v. New Brunswick, ${ }^{36}$ in which the separation of powers, judicial independence, and the rule of law are employed in arguments overruling legislation. ${ }^{37}$ The separation of powers and judicial independence are themselves properly understood as being contained by the deeper principle of the rule of law - a conclusion, particularly in regard to judicial independence, that is supported by an enormous weight of academic commentary. ${ }^{38}$ In Imperial Tobacco, Justice Major himself expressly acknowledges that legislation is subject to the principle of judicial independence. ${ }^{39}$ If judicial independence is a component of the rule of law, and if judicial independence can countenance limitations on legislative power, Justice Major's strictures regarding the institutional ambit of the rule of law are particularly hard to follow.

I conclude that the attempt to prioritize legislative text over the rule of law is not consistent with the Supreme Court's prior decisions. Under the architectural model of the Constitution, legislative sovereignty is an unwritten rule of the utmost importance, being derived directly from the democratic principle. Nevertheless, this rule is subject, in appropriate circumstances, to structural imperatives arising from other unwritten principles, including the rule of law. ${ }^{40}$

\section{B. EXCLUDING THE UNEXPRESSED}

Narrowing the ambit of the rule of law is not the only notable deviation that Imperial Tobacco takes from prior authorities. Justice Major's approach to the written Constitution itself offers a startling change in perspective, for he employs a strategy of statutory interpretation known as expressio unius est exclusio alterius (expressio unius). Expressio unius provides that a deliberate choice made by the framers of a text is to be interpreted as

Antonio Lamer, "The Rule of Law and Judicial Independence: Protecting Core Values in Times of Change" (1996) 45 UNBLJ 3 at 11 [emphasis in original]. 2002 SCC 13 [Mackin].

In Mackin, the Supreme Court states that the depoliticization of institutional relationships involving the judiciary mandated by the Judges Reference "is a structural requirement of the Canadian Constitution resulting from the separation of powers and the rule of law" (ibid at para 69). In the Judges Reference, the rule of law is central to the "constitutional role" of the courts, and provides the logic necessitating judicial independence: supra note 1 at paras 123-46; and see the discussion of the Judges Reference in Johnson, supra note 9 at 1094-1102.

See e.g. Peter W Hogg \& Cara F Zwibel, "The Rule of Law in the Supreme Court of Canada" (2005) 55:3 UTLJ 715 at 716-17, 728; David Beetham, The Legitimation of Power, 2nd ed by B Guy Peters, Jon Pierre \& Gerry Stoker (Basingstoke, UK: Palgrave MacMillan, 2013) at 123-24; Paul R Verkuil, "Separation of Powers, The Rule of Law and the Idea of Independence" (1989) 30:2 Wm \& Mary L Rev 301 at 305-308; Joseph Raz, "The Rule of Law and its Virtue" in The Authority of Law: Essays on Law and Morality, 2nd ed (New York: Oxford University Press, 2009) 210 at 216-17; Scheuerman, supra note 30 at 70

Supra note 11 at para 66 .

In Babcock, supra note 14, the Supreme Court states at para 54 [emphasis added] that

$[\mathrm{t}]$ he respondents in this case challenge the constitutionality of s. 39 and argue that the provision is ultra vires Parliament because of the unwritten principles of the Canadian Constitution: the rule of law, the independence of the judiciary, and the separation of powers. Although the unwritten constitutional principles are capable of limiting government actions, I find that they do not do so in this case.

Given that legislation was at issue in this decision, there is no reason to give "government actions" the narrower institutional range (executive and judiciary) suggested by Justice Major in Imperial Tobacco. 
excluding other unstated choices. As Mark Carter points out, ${ }^{41}$ expressio unius is at work in the following passage:

\begin{abstract}
$[\mathrm{M}]$ any of the requirements of the rule of law proposed by the appellants are simply broader versions of rights contained in the Charter. For example, the appellants' proposed fair trial requirement is essentially a broader version of s. 11(d) of the Charter, which provides that "[a]ny person charged with an offence has the right ... to . . . a fair and public hearing." But the framers of the Charter enshrined that fair trial right only for those "charged with an offence." If the rule of law constitutionally required that all legislation provide for a fair trial, s. 11(d) and its relatively limited scope (not to mention its qualification by s. 1) would be largely irrelevant because everyone would have the unwritten, but constitutional, right to a "fair ... hearing".... Thus, the appellants' conception of the unwritten constitutional principle of the rule of law would render many of our written constitutional rights redundant and, in doing so, undermine the delimitation of those rights chosen by our constitutional framers. ${ }^{42}$
\end{abstract}

The strategy of expressio unius is toxic to the entire theory of the Constitution outlined in the Judges Reference and the Secession Reference. In the Judges Reference, the Supreme Court states that "there are serious limitations to the view that the express provisions of the Constitution comprise an exhaustive and definitive code for the protection of judicial independence," 43 and in the Secession Reference, texts are likewise "not exhaustive," as is evident from the "broader principle" of the protection of minority rights that is deduced from a range of written provisions. ${ }^{44}$ Expressio unius approaches text as effectively occupying the field and crowding out unwritten rules that may be equally critical to constitutional structure. By contrast, an unwritten principles approach to constitutionalism, as Mark D. Walters stresses, is based on the proposition that texts can never fully embrace a nation's constitution, for they are "evidence of supreme law, rather than ... a single canonical statement of supreme law."45

\title{
C. "NECESSARY IMPLICATION": A TEXTUAL THRESHOLD
}

The most important feature of Imperial Tobacco's textualist agenda is likely the suggestion, found in the following passage, that any attempt to interrogate legislation must be mediated by text:

[T] he appellants' arguments overlook the fact that several constitutional principles other than the rule of law that have been recognized by this Court — most notably democracy and constitutionalism — very strongly

$41 \quad$ Mark Carter, "The Rule of Law, Legal Rights in the Charter, and the Supreme Court's New Positivism" (2008) 33:2 Queen's LJ 453 at 465-68. While Carter is critical of doctrinal inconsistencies in the Supreme Court's move towards a "new positivism," he is largely in favour of a re-prioritization of written text, suggesting it is a "welcome development" (ibid at 485).

42 Imperial Tobacco, supra note 11 at para 65 [emphasis added].

43 Supra note 1 at para 85, and generally paras 83-109, 123-46. On the inconsistency between Imperial Tobacco's exclusivist reading of text and the Judges Reference, see also Carter, supra note 41 at 466-68; Vincent Kazmierski, "Draconian but not Despotic: The 'Unwritten' Limits of Parliamentary Sovereignty in Canada" (2009-2010) 41:2 Ottawa L Rev 245 at 274-75.

$44 \quad$ Supra note 2 at paras $32,79-82$.

45 Mark D Walters, "Written Constitutions and Unwritten Constitutionalism," in Grant Huscroft, ed, Expounding the Constitution: Essays in Constitutional Theory (New York: Cambridge University Press, 2008) 245 at 264-65, 273-75. 
favour upholding the validity of legislation that conforms to the express terms of the Constitution (and to the requirements, such as judicial independence, that flow by necessary implication from those terms). ${ }^{46}$

While the modifying phrase "very strongly favour" does leave some room to manoeuvre, the overall suggestion here is that legislation should be upheld absent a textual warrant. Unwritten sources of authority — which are relegated to parentheses in a manner consistent with Imperial Tobacco's overall prioritization of text - evidently must be anchored in "express terms" of the Constitution before legislation can be impugned. This "necessary implication" requirement has been strongly recommended by several academic commentators writing in the wake of the Judges Reference and the Secession Reference, most notably Robin Elliot ${ }^{47}$ and Patrick Monahan. ${ }^{48}$ I respectfully suggest, however, that such a requirement runs into two substantial problems: inconsistency with prior doctrine and an ironic tendency to render text itself "amorphous."

The doctrinal problem arises because none of the earlier unwritten principles decisions relies on an analysis where necessary implications are drawn from the "express terms" of text. To the contrary, these decisions are predicated on necessary implications drawn from the structure of the Constitution as a whole. In the Manitoba Language Reference and New Brunswick Broadcasting, for example, the Supreme Court's unwritten principles analyses are not expressly anchored in textual provisions, and it is worth emphasizing that these two judgments involve halting the operation of constitutional text itself, which is surely of greater significance than overruling legislation. ${ }^{49}$ In MacMillan Bloedel, as discussed above, the Supreme Court relies on the rule of law, and while there is mention made of the judicature provisions of the Constitution Act, $1867,{ }^{50}$ these provisions do not form the backbone of the rule of law analysis that leads to the dramatic result of overruling legislation. ${ }^{51}$ In the Judges Reference, the Supreme Court ostensibly overrules legislation and executive orders intruding on the independence of the judiciary on the basis of section 11(d) of the Charter, but nevertheless leaves no doubt that the "constitutional imperative" of judicial independence is grounded in the structure of the Constitution and necessitates the same result. ${ }^{52}$ Far from

Supra note 11 at para 66 [emphasis added].

Robin Elliot, "References, Structural Argumentation and the Organizing Principles of Canada's Constitution" (2001) 80:1-2 Can Bar Rev 67 at 86, 141-42.

Patrick J Monahan, "The Public Policy Role of the Supreme Court of Canada in the Secession Reference" (1999) 11 NJCL 65 at 75-77; Patrick Monahan, "The Legal Framework Governing Secession in Light of the Quebec Secession Reference," in Special Lectures 2001: Constitutional and Administrative Law (Toronto: Law Society of Upper Canada, 2002) 205 at 218-20. See also Newman, supra note 13 at $217,227-28$ on the "necessary implication" standard.

As Marc Ribeiro, supra note 33 at 49, aptly observes,

the unwritten principle in New Brunswick Broadcasting can be said to have been given an even greater status than the one of striking down legislation, namely, the power to prevent the application of a constitutional enactment such as the Charter.

Professor Elliot's advocacy for a "necessary implication" standard notably fails to address the significance of either New Brunswick Broadcasting or the Manitoba Language Reference (see Elliot, supra note 47 at $83, \mathrm{n} 61)$.

(UK), 30 \& 31 Vict, c 3, reprinted in RSC 1985, Appendix II, No 5.

Section 96 of the Constitution Act, 1867 figures prominently in earlier portions of the majority judgment in MacMillan Bloedel, where the Supreme Court considers whether a grant of superior court jurisdiction to an inferior court is permissible, but section 96 is not relied on in determining whether such a grant of jurisdiction can be exclusive (see my discussion under Part II.A, above). 
finding that this "imperative" is rooted in "express terms" of the text, the Supreme Court in the Judges Reference appears to suggest the exact opposite:

\begin{abstract}
Notwithstanding the presence of s. 11(d) of the Charter, and ss. 96-100 of the Constitution Act, 1867, I am of the view that judicial independence is at root an unwritten constitutional principle, in the sense that it is exterior to the particular sections of the Constitution Acts... The specific provisions of the Constitution Acts, 1867 to 1982, merely "elaborate that principle in the institutional apparatus which they create or contemplate": Switzman v. Elbling. ${ }^{53}$
\end{abstract}

None of the above decisions leads to the "necessary implication" standard advanced in Imperial Tobacco. The same can also be said of OPSEU. It is "basic constitutional structure," and not text, that leads to the conclusion that legislatures cannot threaten political freedoms: "quite apart from Charter considerations, the legislative bodies in this country must conform to these basic structural imperatives and can in no way override them." Court's unwritten principles jurisprudence stands for the proposition that it is the "architecture" of the Constitution itself that is determinative: texts are a crucial but not an "exhaustive" part of this architecture. ${ }^{55}$

The second problem with imposing a "necessary implication" standard on the use of unwritten principles to overrule legislation is that this standard can ironically function to debase the importance of "express" textual language. It will be recalled that Imperial Tobacco distinguishes between "amorphous underlying principles" and the precision and clarity of text. But if the authority of clearly posited text is in any way strained, for example by a judge seeking to meet a "necessary implication" standard, there is a danger that text can itself become "amorphous." To make this point clearer, it is worth briefly considering Justice La Forest's dissent in the Judges Reference. This dissent, which commentators critical of the unwritten principles approach to the Constitution have variously characterized as "powerful," "sobering," and "devastating," 56 outlines a very text-centered approach to the Constitution and to the legitimacy of judicial review:

The ability to nullify the laws of democratically elected representatives derives its legitimacy from a superlegislative source: the text of the Constitution.

This legitimacy is imperiled, however, when courts attempt to limit the power of legislatures without recourse to express textual authority.

Ibid at para 83, citing Switzman v Elbling, [1957] SCR 285 at 306 [citation omitted].

OPSEU, supra note 28 at 57.

Secession Reference, supra note 2 at paras 32, 50.

WH Hurlburt, "Fairy Tales and Living Trees: Observations on Some Recent Constitutional Decisions of the Supreme Court of Canada" (1998-1999) 26:2 Man LJ 181 at 182; Leclair, supra note 13 at 396; Jeffrey Goldsworthy, "The Preamble, Judicial Independence and Judicial Integrity" (2000) 11:2 Const Forum Const 60 at 61. See also Peter W Hogg, Constitutional Law of Canada, 5th ed (Toronto: Thomson Reuters, 2007) at 7-25 to 7-26. 
The legitimacy of this interpretive exercise stems from its grounding in an expression of democratic will, not from a dubious theory of an implicit constitutional structure. The express provisions of the Constitution are not, as the Chief Justice contends, "elaborations of the underlying, unwritten, and organizing principles found in the preamble to the Constitution Act, 1867'. On the contrary, they are the Constitution. To assert otherwise is to subvert the democratic foundation of judicial review. ${ }^{57}$

These comments in some respects mark out the very terrain that the Supreme Court attempts to occupy in Imperial Tobacco. ${ }^{58}$ Justice La Forest eschews a "dubious theory of an implicit constitutional structure," preferring instead the concreteness of written authority, yet difficulties arise in that he participated in several unwritten principles decisions prior to the Judges Reference, including OPSEU (part of the majority), New Brunswick Broadcasting (concurring opinion), and MacMillan Bloedel (part of the majority). While there is no mention in his Judges Reference dissent of the fairly recently decided MacMillan Bloedel (arguably a substantial omission), Justice La Forest does attempt to accommodate both New Brunswick Broadcasting and OPSEU through what is, in essence, an Imperial Tobacco-style "necessary implication" standard. In particular, he looks to the grant of legislative assemblies in the Constitution Act, 1867 to ground unwritten principles in "express textual authority." Sections 17, 69, and 71 of the Constitution Act, 1867 grant legislative assemblies to each of Canada, Ontario, and Quebec, and section 88 continues the existing grants of legislative assemblies to Nova Scotia and New Brunswick. These textual provisions, however, are very sparsely worded, and none speak to the matter of legislative privilege (at issue in New Brunswick Broadcasting) or political freedoms (discussed in OPSEU). Section 17, for example, provides that " $\mathrm{t}]$ here shall be One Parliament for Canada, consisting of the Queen, an Upper House styled the Senate, and the House of Commons." 60

When Justice La Forest stresses the need for "express textual authority" to overrule legislation, section 2 of the Charter is the obvious standard as far as the protection of political freedoms (OPSEU) is concerned. By contrast, the simple grant of a legislature, memorialized in the Constitution Act, 1867, leaves a great deal of space to be filled by judicial interpretation. This space undermines Justice Major's distinction, in Imperial Tobacco, between the clarity and precision of text and "amorphous underlying principles." Text itself becomes "amorphous" in the sense of being open to wide-ranging judicial interpretations. It is not at all clear how Justice La Forest's use of the grant of a legislature in section 17 offers any firmer foundation for a legal argument than, say, the "amorphous" democratic principle, which is what the Supreme Court employs in OPSEU. Indeed, the Secession Reference finds the democratic principle to be so fundamental to the Canadian Constitution that it requires no explicit textual foundation. ${ }^{61}$

57 Judges Reference, supra note 1 at paras 314, 316, 319 [citation omitted] [emphasis added].

Justice Major appears to echo Justice La Forest in the following statement: "[A]nything resembling the appellants' conceptions of the rule of law would seriously undermine the legitimacy of judicial review of legislation for constitutionality" (Imperial Tobacco, supra note 11 at para 64).

Judges Reference, supra note 1 at paras 303, 318. See also Justice La Forest's concurrence in New Brunswick Broadcasting, supra note 7 at 368: "Parliamentary legislative privileges in Nova Scotia are, therefore, ultimately anchored in the grant of a legislative assembly and incorporated into the Constitution Act, 1867."

Supra note 50.

61 Secession Reference, supra note 2 at para 62 [citation omitted]:

$[\mathrm{T}]$ he democracy principle can best be understood as a sort of baseline against which the framers of our Constitution, and subsequently, our elected representatives under it, have always operated. It is perhaps for this reason that the principle was not explicitly identified in the text of the 
A "necessary implication" standard arguably does nothing but relocate the arena of judicial discretion from a space where unwritten principles are transparently worked on through legal reasoning to a space where they are obscured by often stained invocations of text. As the American constitutional scholar Charles L. Black puts it, in his pioneering work on structural approaches to the United States Constitution, "[ $\mathrm{t}]$ he precision of textual explication is nothing but specious in the areas that matter." ${ }^{62}$ A standard authorizing a court to ground an argument somewhere in the proximity of a textual provision defeats the very purpose of demanding reliance on text in the first place, which is to promote legal certainty. Legal certainty is a value of the utmost importance. The Supreme Court's unwritten principles jurisprudence does not discard or question this value, but rather acknowledges that texts cannot exhaust the content of the laws constituting a democratic society. The "necessary implication" standard advanced in Imperial Tobacco is an unsatisfying attempt to contain unwritten sources of authority, and as I discuss below, it leads to strained reasoning in Trial Lawyers.

\section{TRIAL LAWYERS: RENDERING TEXT "AMORPHOUS"}

Imperial Tobacco is notably absent from a lecture given by Chief Justice Beverley McLachlin shortly after the decision, a lecture affirming that "fundamental constitutional principles" occupy the "highest" position in the Canadian Constitution. ${ }^{63}$ Imperial Tobacco is also absent from the 2014 Senate Reference, in which the Supreme Court addressed the extent of provincial cooperation required to make fundamental changes to the Canadian Senate, and took the opportunity to reaffirm, in the strongest possible terms, the earlier unwritten principles decisions:

Generally, constitutional interpretation must be informed by the foundational principles of the Constitution, which include principles such as federalism, democracy, the protection of minorities, as well as constitutionalism and the rule of law: Secession Reference; Provincial Court Judges Reference; New Brunswick Broadcasting...; Manitoba Language Rights....

Constitution Act, 1867 itself. To have done so might have appeared redundant, even silly, to the framers. As explained in the Provincial Judges Reference ... it is evident that our Constitution contemplates that Canada shall be a constitutional democracy. Yet this merely demonstrates the importance of underlying constitutional principles that are nowhere explicitly described in our constitutional texts. The representative and democratic nature of our political institutions was simply assumed.

62 Charles L Black, Jr, Structure and Relationship in Constitutional Law (Baton Rouge: Louisiana State University Press, 1969) at 29. Black discusses numerous landmark United States Supreme Court decisions, and he argues that results purportedly reached on the basis of constitutional text were in fact derived from what he refers to as "structural" analysis (ibid at 8-31).

63 The Chief Justice states that

[t]he role of judges in a democracy is to interpret and apply the law. The law involves rules of different orders. The highest is the order of fundamental constitutional principles. These are the rules that guide all other law-making and the exercise of executive power by the state. More and more in our democratic states, we try to set these out in writing. But when we do not, or when, as is inevitable, the written text is unclear or incomplete, recourse must be had to unwritten sources. The task of the judge, confronted with conflict between a constitutional principle of the highest order on the one hand, and an ordinary law or executive act on the other, is to interpret and apply the law as a whole - including relevant unwritten constitutional principles (Chief Justice Beverley McLachlin, "Unwritten Constitutional Principles: What is Going On?" (Remarks delivered at the 2005 Lord Cooke Lecture, Wellington, New Zealand, 1 December 2005) at 22, online: $<$ www.fact.on.ca/judiciary/NewZeal. pdf $>$ ). 
These rules and principles of interpretation have led this Court to conclude that the Constitution should be viewed as having an "internal architecture", or "basic constitutional structure": Secession Reference..., OPSEU.... The notion of architecture expresses the principle that "[ $\mathrm{t}]$ he individual elements of the Constitution are linked to the others, and must be interpreted by reference to the structure of the Constitution as a whole": Secession Reference...; see also the discussion on this Court's approach to constitutional interpretation in M. D. Walters, "Written Constitutions and Unwritten Constitutionalism". In other words, the Constitution must be interpreted with a view to discerning the structure of government that it seeks to implement. $^{64}$

The approving reference to Professor Walters' article on unwritten constitutionalism is pinpointed to a discussion that contains the following evocative description of the theory of the Constitution outlined in the Judges Reference and the Secession Reference:

The textual islands are merely the exposed parts of a vast seabed visible beneath the surrounding waters, and the bridges constructed by judges between these islands are actually causeways moulded from natural materials brought to the surface from this single underlying foundation. The constitutional text is not just supplemented by unwritten principles; it rests upon them. ${ }^{65}$

The forceful textualism of Imperial Tobacco appears quite discordant when set between the Judges Reference and the Secession Reference, on the one hand, and the Senate Reference, on the other.

It is conceivable that Imperial Tobacco is not mentioned in the Senate Reference because legislation was not challenged in the latter decision and unwritten principles supported textual analysis. Imperial Tobacco is very present, however, in the 2014 decision of Trial Lawyers, in which legislative competence is in issue, along with the relationship between text and the rule of law. Trial Lawyers addresses the constitutional ambit of access to justice, specifically in the context of hearing fees. A British Columbia hearing fees regime contained an exception for litigants in financial need, but both the Court of Appeal and the Supreme Court of Canada found that the exemption was unconstitutionally narrow, leaving some litigants without access to the courts. The Court of Appeal responded by reading in a broader exemption. ${ }^{6}$ A five-member majority of the Supreme Court, in an opinion written by Chief Justice McLachlin, struck the regime down.

Because the impugned hearing fees regime was in the form of subordinate legislation (court rules enacted under statutory authority ${ }^{67}$ ), Trial Lawyers could have been resolved entirely on administrative law grounds and Imperial Tobacco would not have been relevant. Justice Cromwell opted for this approach in his concurring reasons, finding that there was no statutory authority for hearing fees that limited access to justice. ${ }^{68}$ This strategy allowed for a very brief resolution of the matter. The majority of the Supreme Court, however, chose 
to approach the issue on a constitutional basis and expressly phrased its reasons in terms that captured legislative competence, and not just the vires of subordinate enactments:

In the context of legislation which effectively denies people the right to take their cases to court, concerns about the maintenance of the rule of law are not abstract or theoretical. If people cannot challenge government actions in court, individuals cannot hold the state to account - the government will be, or be seen to be, above the law.

Nor does the argument that legislatures generally have the right to determine the cost of government services undermine the proposition that laws cannot prevent citizens from accessing the superior courts. (Indeed, the Attorney General does not assert such a proposition.) The right of the province to impose hearing fees is limited by constitutional constraints. In defining those constraints, the Court does not impermissibly venture into territory that is the exclusive turf of the legislature. Rather, the Court is ensuring that the Constitution is respected. ${ }^{69}$

While the Supreme Court's choice to address the scope of provincial legislative power moved the decision into the path of Imperial Tobacco, the additional choice to advance a rule of law argument set up a collision.

The primary ground on which Trial Lawyers determines that access to the courts is a constitutional imperative is section 96 of the Constitution Act, 1867. The argument is essentially that section 96 protects the "core jurisdiction" of the superior courts and hearing fees that deny claimants access to these courts infringe this jurisdiction, and thus are unconstitutional. ${ }^{70}$ But Chief Justice McLachlin also provided a separate rule of law analysis that also leads to the conclusion that access to the courts is a constitutional imperative, and at this point, Trial Lawyers moves into direct conflict with Imperial Tobacco. Justice Rothstein, in a sharply worded and extremely text-centered dissenting opinion, demanded that the limited approach to the rule of law mandated by Imperial Tobacco be maintained: "To rely on this nebulous principle to invalidate legislation based on its content introduces uncertainty into constitutional law and undermines our system of positive law.",71

With a section 96 argument in play, and with Imperial Tobacco (and Justice Rothstein) demanding that the rule of law not be used to challenge legislative power, the burning question posed by Trial Lawyers is why the Supreme Court raised this unwritten principle at all. I respectfully submit that the answer to this question is that the section 96 argument is strained, whereas the rule of law argument is straightforward. Casting aside Imperial Tobacco's strictures on the rule of law (themselves doctrinally and theoretically problematic, as discussed above) was infinitely preferable than basing the entire judgment on a fragile textual argument. In this sense, Trial Lawyers may be an example of a classic unwritten principles situation of the kind encountered in the earlier decisions from the Manitoba 
Language Reference through to the Secession Reference: a constitutional threat (in this case, denying citizens access to justice) with no solid textual solution.

I address three points under separate headings below: the strained section 96 argument, the separate rule of law argument, and the lingering hold of Imperial Tobacco on Trial Lawyers through the "necessary implication" requirement.

\section{A. SECTION 96 DOCTRINE AND THE "BASIC JUdiciaL FUNCTION" OF THE SUPERIOR COURTS}

In Trial Lawyers, the Supreme Court finds that the imposition of hearing fees is within the scope of section 92(14) of the Constitution Act, 1867, which gives the provinces control over the "Administration of Justice in the Province, including the Constitution, Maintenance, and Organization of Provincial Courts." ${ }^{\prime 2}$ But Chief Justice McLachlin also stresses that the exercise of the section 92(14) power must be consistent with section 96, and in particular with the "core jurisdiction" of the superior courts that is protected by section $96 .{ }^{73}$ Section 96 states that " $[\mathrm{t}]$ he Governor General shall appoint the Judges of the Superior, District, and County Courts in each Province, except those of the Courts of Probate in Nova Scotia and New Brunswick." 74 This is a "staffing provision,"75 but because this "staffing" language does not speak directly to the jurisdiction of the superior courts, let alone the concept of a core jurisdiction, which is controversial, ${ }^{76}$ Trial Lawyers relies extensively on judicial interpretations of section 96 . The relevant precedents are concerned with the specific judicial powers that constitute the jurisdiction of the superior courts, and especially with the question of whether this jurisdiction can be transferred or removed. Significantly however, Trial Lawyers fails to isolate a specific judicial power of the type found in the authorities and instead advances only a very abstract conception of the overall function of the courts. As a result, the entire section 96 analysis appears strained.

The following paragraph forms the basis of the argument:

The historic task of the superior courts is to resolve disputes between individuals and decide questions of private and public law. Measures that prevent people from coming to the courts to have those issues resolved are at odds with this basic judicial function. The resolution of these disputes and resulting determination of issues of private and public law, viewed in the institutional context of the Canadian justice system, are central to what the superior courts do. Indeed, it is their very book of business. To prevent this business being done strikes at the core of the jurisdiction of the superior courts protected by s. 96 of the Constitution Act, 1867. As a result, hearing fees that deny people access to the courts infringe the core jurisdiction of the superior courts. $^{77}$

Ibid at para 21; Constitution Act, 1867, supra note 50.

Trial Lawyers, ibid at paras 24, 32.

Constitution Act, 1867, supra note 50.

Judges Reference, supra note 1 at para 88.

Peter Hogg has strongly rejected the concept of core jurisdiction, and has argued that the relevant section 96 decisions are "unfortunate and needless" and "intolerably uncertain" (supra note 56 at 7-50 to 7-52). With Cara Zwibel, Hogg has commented that the "the arcane jurisprudence surrounding s. 96 ... has inflated a power of appointment of superior court judges into a guarantee of superior court jurisdiction" (supra note 38 at 731). It is worth noting that in the leading decision, MacMillan Bloedel, the Supreme Court was divided 5-4 on the issue of core jurisdiction. 
It can be said that access to the courts is a fundamental right possessed by individual citizens and is a concrete manifestation of the more abstract concept of access to justice. ${ }^{78}$ As Roderick A. MacDonald observes, access to justice contemplates "an equal right to participate in every institution where law is debated, created, found, organized, administered, interpreted and applied." ${ }^{, 79}$ In the first four sentences of the above passage, Trial Lawyers approaches this "right to participate" from an institutional perspective: if citizens cannot enter the courts, the courts cannot perform their "basic judicial function." But rather than attempt to formulate a constitutional imperative directly from this functional relationship between citizens and a critically important state institution, the Supreme Court introduces the concept of core jurisdiction in the last two sentences. At this point, section 96 jurisprudence takes over the argument:

The thread throughout these cases is that laws may impinge on the core jurisdiction of the superior courts by denying access to the powers traditionally exercised by those courts.

In Residential Tenancies, the law at issue unconstitutionally denied access to the superior courts by requiring that a certain class of cases be decided by an administrative tribunal. In Crevier, the law at issue unconstitutionally denied access to the superior courts by imposing a privative clause excluding the supervisory jurisdiction of the superior courts. In MacMillan Bloedel, the legislation at issue unconstitutionally barred access to the superior courts for a segment of society — young persons — by conferring an exclusive power on youth courts to try youths for contempt in the face of superior courts. ${ }^{80}$

Yet, the three decisions discussed - Re Residential Tenancies Act, $1979 ;{ }^{81}$ Crevier v. Quebec $(A G){ }^{82}$ and MacMillan Bloedel — are all concerned with very specific judicial powers, and not with "basic judicial function" in the abstract. ${ }^{83}$ Indeed, two of the decisions, Residential Tenancies and MacMillan Bloedel, are so concerned with specific superior court powers that recasting them to meet the needs of Trial Lawyers is troubling.

In Residential Tenancies, the Supreme Court held that judicial powers exercised exclusively by the superior courts in 1867 cannot be transferred to provincially created courts and tribunals unless the power in question is modified to become "merely subsidiary or ancillary to general administrative functions assigned to the tribunal." ${ }^{84}$ Isolating and

78 See BCGEU v British Columbia (Attorney General), [1988] 2 SCR 214 at 219, commenting on "the fundamental right of every Canadian citizen to have unimpeded access to the courts and the authority of the courts to protect and defend that constitutional right."

79 Roderick A MacDonald, “Access to Justice in Canada Today: Scope, Scale, Ambitions," in Julia Bass, WA Bogart \& Frederick H Zemans, eds, Access to Justice for a New Century - The Way Forward (Toronto: Law Society of Upper Canada, 2005) 19 at 23.

Trial Lawyers, supra note 18 at paras 33-34.

[1981] 1 SCR 714 [Residential Tenancies].

[1981] 2 SCR 220 [Crevier].

Brooke MacKenzie underlines Trial Lawyers' forced reinterpretation of the precedents:

Residential Tenancies, MacMillan Bloedel, and Crevier were not so much about denying litigants access to the superior courts as denying courts the ability to exercise certain powers..... It is not clear from those cases that denying individuals access to the superior courts was, in itself, an infringement of section 96 - it was the removal of the power from the court that was cause for concern. (Brooke MacKenzie, "Trial Lawyers Association of British Columbia and the Supreme Court's Use of the Constitution to Protect Public Access to the Courts" (2016) 72 SCLR (2d) 485 at 500-501).

84 Supra note 81 at 734-36. On the exclusivity point, see ibid at 738; Quebec (AG) v Grondin, [1983] 2 SCR 364 at $381-83$. 
characterizing a specific judicial power or jurisdiction that has been transferred to an executive body is central to the test that has emerged from Residential Tenancies. ${ }^{85}$

The need to identify a specific power is also crucial in the case of "core jurisdiction," which MacMillan Bloedel determines cannot be removed from the superior courts under a Residential Tenancies analysis:

The full range of powers which comprise the inherent jurisdiction of a superior court are, together, its 'essential character' or 'immanent attribute'. To remove any part of this core emasculates the court, making it something other than a superior court. ${ }^{86}$

The Supreme Court has stressed on numerous occasions that the core jurisdiction of the superior courts is "narrow" and is limited to "critically important jurisdictions," furthermore that "[p]roper characterization of the subject matter of the challenged power is critical." ${ }^{88}$ MacMillan Bloedel isolates three "essential" core powers: (1) control over the processes of court and the enforcement of orders (the power to punish for ex facie contempt was the primary issue in the decision); (2) judicial review of legislation; and (3) judicial review of administrative action. ${ }^{89}$ While this list is not exhaustive, ${ }^{90}$ it is clear that in order for a core power to be carved out of the rest of superior court jurisdiction which is subject to the Residential Tenancies test, precise definition is required.

In Trial Lawyers, the attempt to cast the broadly conceived "basic judicial function" of the superior courts as an element of core jurisdiction runs counter to the precision required under the above decisions. The hearing fees at issue in Trial Lawyers simply do not lend themselves to a section 96 analysis. Thus Justice Rothstein, in his dissenting opinion, concludes that

no aspect of the core jurisdiction of superior courts is removed by legislation that merely places limits on access to superior courts. In the absence of any demonstrated destruction of the core powers of the superior courts, there is no such removal sufficient to find a violation of s. $96 .^{91}$

A further difficulty with the Supreme Court's attempt to fold the concept of access to the courts into the above-noted jurisprudence is the very characterization of Residential Tenancies as a core jurisdiction decision. The jurisdiction of the superior courts can be said to be either "core" or "non-core": the former cannot be removed, pursuant to MacMillan Bloedel, while the latter can be removed, subject to Residential Tenancies. ${ }^{92}$ Residential

See Residential Tenancies, ibid at 734-36; Sobeys Stores Ltd v Yeomans and Labour Standards Tribunal (NS), [1989] 1 SCR 238 at 252-56 [Yeomans]; Reference re Amendments to the Residential Tenancies Act (NS), [1996] 1 SCR 186 at paras 32-35, 76 [Residential Tenancies NS].

86 MacMillan Bloedel, supra note 8 at para 30, citing IH Jacob, "The Inherent Jurisdiction of the Court" (1970) 23:1 Current Leg Probs 23 at 27. See generally MacMillan Bloedel, ibid at paras 26-42.

87 Babcock, supra note 14 at para 59 [emphasis added]; Ontario v Criminal Lawyers' Association of Ontario, 2013 SCC 43 at para 19 [emphasis added]. Both of these decisions cite Chief Justice Lamer's opinion in Residential Tenancies NS, supra note 85 at para 56.

$R v$ Ahmad, 2011 SCC 6 at para 62 [emphasis added].

Supra note 8 at paras 33-36. Crevier involved an attempt to remove the third core power.

MacMillan Bloedel, ibid at para 33.

Trial Lawyers, supra note 18 at para 90.

See Residential Tenancies NS, supra note 85 at paras $56-57$. 
Tenancies is thus not a core jurisdiction decision at all, and arguably contradicts the functional argument advanced in Trial Lawyers, which is worth restating:

The historic task of the superior courts is to resolve disputes between individuals and decide questions of private and public law. Measures that prevent people from coming to the courts to have those issues resolved are at odds with this basic judicial function. ${ }^{93}$

Pursuant to Residential Tenancies, legislatures can transfer "non-core" dispute-resolution powers that were part of the "historic task of the superior courts." By extension, legislatures can enact "[m] easures that prevent people from coming to the courts." 94 As Justice McLachlin (as she then was) observes in her dissenting opinion in MacMillan Bloedel,

the issue [in a Residential Tenancies analysis] is almost always whether Parliament or the legislatures can transfer the s. 96 power to the inferior tribunal and exclude the s. 96 courts from adjudication in that area. ${ }^{95}$

Because Trial Lawyers relies so heavily on section 96 jurisprudence, any inconsistency in the application of the precedents is of the greatest significance. Neither Trial Lawyers, nor MacMillan Bloedel for that matter, explain exactly how the "staffing" language of section 96 translates into the doctrine of core jurisdiction. ${ }^{96}$ The access to the courts extension of this doctrine in Trial Lawyers ultimately lacks a firm foundation in the cited decisions and in the text of the Constitution itself. The source of the provincial legislative power to impose hearing fees, on the other hand, requires no jurisprudential intervention. The language of section 92(14) speaks directly to the "Administration of Justice."

\section{B. The Simplicity of The Rule OF LAW ANALysiS}

It will be recalled that Justice Rothstein, in his dissenting opinion in Trial Lawyers, argues that relying on the "nebulous principle" of the rule of law "to invalidate legislation based on its content introduces uncertainty into constitutional law and undermines our system of positive law." ${ }^{\prime 97}$ The above discussion, however, suggests that judicial doctrine and constitutional text, which are the hallmarks of "positive law," themselves offer at best a "nebulous" path to challenge the provincial power to impose hearing fees.

The reason that the Supreme Court opens a second argument in Trial Lawyers based on unwritten principles is likely to offset the difficulty of the textual analysis. Access to justice, as noted previously, implicates individual rights. The rule of law provides the clearest path to establish a constitutional imperative protecting such rights:

\section{$93 \quad$ Supra note 18 at para 32.}

$94 \quad$ See e.g. Yeomans, supra note 85; Residential Tenancies NS, supra note 85.

95 Supra note 8 at para 75 [emphasis in original]. See also ibid at para 27, per Lamer CJC.

96 Trial Lawyers simply observes that "[a]lthough the bare words of s. 96 refer to the appointment of judges, its broader import is to guarantee the core jurisdiction of provincial superior courts" (supra note 18 at para 29). As for MacMillan Bloedel, a brief passage early in the decision connecting core jurisdiction with section 96 (supra note 8 at para 15) is at odds with Chief Justice Lamer's extra-judicial statement, discussed previously, that "while s. 96 was integral to the Court's ruling on the validity of the grant of jurisdiction to the youth courts over contempt ex facie by young offenders, it played no direct role in the ruling on the validity of the removal of that same jurisdiction from the superior courts" (supra note 35 at 11 [emphasis in original]). Indeed, it was necessary "in MacMillan Bloedel, to go beyond s. 96 in explaining the Court's decision to strike down the legislation" (ibid). 
In the context of legislation which effectively denies people the right to take their cases to court, concerns about the maintenance of the rule of law are not abstract or theoretical. If people cannot challenge government actions in court, individuals cannot hold the state to account - the government will be, or be seen to be, above the law. If people cannot bring legitimate issues to court, the creation and maintenance of positive laws will be hampered, as laws will not be given effect. And the balance between the state's power to make and enforce laws and the courts' responsibility to rule on citizen challenges to them may be skewed: Christie v. British Columbia (Attorney General), 2005 BCCA 631. ${ }^{98}$

The central sentence here, "If people cannot bring legitimate issues to court, the creation and maintenance of positive laws will be hampered, as laws will not be given effect," paraphrases the Manitoba Language Reference. In that decision, the Supreme Court observes that the rule of law is "a fundamental postulate of our constitutional structure," and "requires the creation and maintenance of an actual order of positive laws which preserves and embodies the more general principle of normative order." ${ }^{99}$ In the Secession Reference, the Supreme Court adds that "the rule of law vouchsafes to the citizens and residents of the country a stable, predictable and ordered society in which to conduct their affairs." 100 It follows as a pragmatic correlative of the proposition that the state must provide stability through "an actual order of positive laws," that there must be an accessible public institution that can authoritatively interpret and apply those laws. The Supreme Court's conclusion in Trial Lawyers thus flows logically from the operative unwritten principle: "the creation and maintenance of positive laws" requires access to the courts.

The rule of law reasoning in Trial Lawyers follows very closely that of the cited decision of Christie v. British Columbia. ${ }^{101}$ A mere three weeks after Imperial Tobacco was decided, the British Columbia Court of Appeal had to consider a lower court ruling that struck down legislation imposing a tax on legal services on the grounds that such a tax violated the principles of access to justice and the rule of law. ${ }^{102}$ A special five-member Panel of the Court of Appeal divided 3-2, with the dissenting Justices adopting an extremely textcentered approach, relying on Imperial Tobacco for the proposition that a statute could not be overruled on the basis of unwritten sources of authority. ${ }^{103}$ The majority, on the other hand, relied on the rule of law and expanded the scope of the trial judge's declaration of invalidity. Justice Newbury, writing for the majority, provided a detailed summary of the relevant Supreme Court of Canada unwritten principles decisions, ${ }^{104}$ and very carefully used access to justice to pry open holes in Imperial Tobacco's reasoning on both the limited scope of the rule of law and the "necessary implication" requirement. ${ }^{105}$ I return to the latter requirement under the next heading. On the former point, Justice Newbury stressed that the legal system itself cannot function without access to justice:

$[N]$ o law, not even the written text of the Constitution, can be given effect to if access to justice is denied.

Ibid at para 40 .

Manitoba Language Reference, supra note 6 at 749-50 [emphasis added].

Supra note 2 at para 70.

2005 BCCA 631 [Christie].

Christie v AG of BC, 2005 BCSC 122 at paras 83-88. An earlier decision also cast strong doubt on the constitutionality of the legislation: John Carten Personal Law Corp v British Columbia (Attorney General) (1997), 153 DLR (4th) 460 (BCCA), leave to appeal to SCC refused, [1998] 2 SCR viii.

Christie, supra note 101 at paras 18-19, 24.

Ibid at paras 46-72.

Ibid at paras 68-70. 
[T] he third component of the rule of law [outlined in Imperial Tobacco], that the relationship between the state and the individual be regulated by law, could not be fulfilled if access to the courts (and, I would add, other independent tribunals exercising quasi-judicial functions) were effectively prohibited. Not only would individuals be unable to have their rights determined vis-à-vis the government or other private persons; governments would also be stymied in the execution of many of their executive and enforcement functions. Viewed in this context, the invocation of access to justice is not a challenge to legislation "based on its content". The principle operates at a more basic — one might even say threshold — level. ${ }^{106}$

The essentials of this analysis are virtually identical to the rule of law argument in Trial Lawyers. Chief Justice McLachlin observes that "[i]f people cannot bring legitimate issues to court, the creation and maintenance of positive laws will be hampered, as laws will not be given effect."107 This covers the exact same constitutional terrain as Justice Newbury's statement that "no law, not even the written text of the Constitution, can be given effect to if access to justice is denied." 108

The rule of law argument in Trial Lawyers and in Christie, like the rule of law argument in other decisions such as the Manitoba Language Reference, involves drawing concrete constitutional imperatives from what Justice Major refers to in Imperial Tobacco as "amorphous" unwritten principles. Abstract principles can take on more concrete legal form in the context of specific legal problems. The reasoning is pragmatic, with a focus on the necessary inferences that can be drawn from the web of structural relationships connecting citizens and the central institutions of the state. ${ }^{109}$ Professor Walters provides a useful way of understanding this methodology when he speaks of "identifying the practical legal implications" that can be drawn from the "forms of constitutionalism to which societies commit themselves." 110 The conclusions reached in Trial Lawyers and in Christie, drawing on the rule of law, are pragmatic and "practical." Indeed, Brooke MacKenzie, commenting on the rule of law passage from Trial Lawyers quoted above, finds that the Supreme Court's argument is "persuasive from a common-sense perspective" and "compelling." 111 The project of constitutionalism to which Canada is committed gives rise to a structural imperative of access to justice. Hearing fees that are overly broad, that have the effect of denying certain members of society access to the courts, are necessarily unconstitutional. The rule of law, unshackled from the strictures of Imperial Tobacco, provides a clean, clear, and concise basis

Ibid at para 68, citing Imperial Tobacco, supra note 11 at para 59.

Trial Lawyers, supra note 18 at para 40.

The Supreme Court of Canada overruled Christie in a very brief judgment that carefully avoided commenting on the Court of Appeal's refusal to follow Imperial Tobacco (British Columbia (Attorney General) v Christie, 2007 SCC 21). Trial Lawyers distinguishes the earlier Supreme Court decision on the basis that the claimant did not adequately establish that the impugned tax on legal services hindered access to justice (Trial Lawyers, supra note 18 at para 41). Nevertheless, when Trial Lawyers expressly adopts Christie's approach to the rule of law, the British Columbia Court's rejection of Imperial Tobacco is at least partially vindicated.

109 See the discussion of inferences drawn from constitutional structure in Johnson, supra note 9 at 1088-93, citing Black, supra note 62 at 7, 13 and Elliot, supra note 47 at 75-77. See also the "pragmatic" argument based on institutional function in New Brunswick Broadcasting, supra note 7 at $385,387-89$. 
on which to resolve the appeal, unlike the more difficult path through section 96 and the core jurisdiction of the courts.

\section{THE SURVIVAL OF IMPERIAL TOBACCO}

In Part II, I argued that Imperial Tobacco departs from the Court's unwritten principles authorities by limiting the ambit of the rule of law, by approaching the text of the Constitution through the strategy of expressio unius, and by imposing a "necessary implication" requirement. Trial Lawyers jettisons the strictures on the rule of law without comment, and likewise appears to abandon an expressio unius approach to constitutional text, as is evident from the following objection made by Justice Rothstein:

[Section] 11(d) of the Charter specifically includes a right of access to the courts for a person charged with an offence and s. 24(1) gives this right to those vindicating their Charter rights. These provisions would be unnecessary if the Constitution already contained a more general right to access superior courts. ${ }^{112}$

It is through Imperial Tobacco's "necessary implication" requirement that Trial Lawyers attempts to maintain some semblance of doctrinal order. Imperial Tobacco is cited twice by the Supreme Court in Trial Lawyers, and both times the "necessary implication" requirement is quoted: first, when the two constitutional arguments are introduced, and second, at the conclusion of the section 96 discussion and just before the shift to the rule of law. ${ }^{113}$

The "necessary implication" requirement, as discussed previously, provides that challenges to legislation must be mediated by the "express terms" of text. In Trial Lawyers, the following passage is inserted in the middle of the rule of law analysis to fulfil the "necessary implication" requirement:

The s. 96 judicial function and the rule of law are inextricably intertwined. As Lamer C.J. stated in MacMillan Bloedel, "[i]n the constitutional arrangements passed on to us by the British and recognized by the preamble to the Constitution Act, 1867, the provincial superior courts are the foundation of the rule of law itself"... The very rationale for the provision is said to be "the maintenance of the rule of law through the protection of the judicial role": Provincial Judges Reference.... As access to justice is fundamental to the rule of law, and the rule of law is fostered by the continued existence of the s. 96 courts, it is only natural that $\mathrm{s}$. 96 provide some degree of constitutional protection for access to justice. ${ }^{114}$

This attempt to bring section 96 into the otherwise convincing discussion of the rule of law is far from satisfying. The language of the "staffing provision" is completely absent from this passage, and in place of textual analysis, the Supreme Court speaks very vaguely of the "s. 96 judicial function." It is very difficult to determine the exact referent of this phrase, which is "inextricably intertwined" with one of Justice Major's "amorphous" unwritten principles. The reference to the "s. 96 courts" is likewise very imprecise. The Supreme Court appears to use section 96 here as a kind of constitutional synecdoche: one specific component of the superior courts (the federal appointment of judges) stands in for the entire institution, and for 
its various alleged attributes and associations (for example, core jurisdiction, rule of law, access to justice). Text itself thus appears "amorphous" — a general repository for a range of complex and weighty legal concepts that need to be clearly and systematically charted and interrelated. The concluding statement in the above passage underlines the failure of section 96 in Trial Lawyers. It is surely remarkable that in a decision concerned with determining the limits of provincial legislative power under section 92(14), and a decision that invokes the strongly text-centered authority of Imperial Tobacco on two occasions, that the Supreme Court could possibly say that section 96 provides "some degree" of protection for access to justice. How can legislation possibly be challenged on such imprecise grounds? Section 96 may well be the worst possible choice of "express terms" to support the "necessary implication" requirement of Imperial Tobacco.

In Christie, the Court of Appeal offers a very useful realignment:

The Court in Imperial Tobacco stated that judicial independence, an unwritten constitutional principle which (as we have seen) has been extensively considered by the Supreme Court of Canada in recent years and used to strike down otherwise valid legislation, was a "requirement that flows by necessary implication" from the express terms of the Constitution. In my view, access to justice may equally be said to flow by necessary implication from the Constitution. If it is important that "courts give effect to the Constitution's text", it must be at least as important that the person (or other entity) seeking to have the text interpreted or applied has access to the courts and to legal services.... In other words, if "the relationship between the state and the individual must be regulated by law" (see Quebec Secession Reference...), the state should not impede access to that law - otherwise, the 'regulating' may not take place. ${ }^{115}$

Rather than focusing on a "necessary implication" drawn from the "express terms" of text, Justice Newbury finds a "necessary implication" in the Constitution as a whole. This larger perspective is consistent with the architectural model. The Court of Appeal offers a remarkably effective rejoinder to Imperial Tobacco by stressing that text is ineffective without the essential relationships (including "access to the courts and to legal services") that support it. Christie's focus is consistently on the larger framework that connects citizens and the institutions of government within a constitutional democracy. The fetish for "express terms" leads Trial Lawyers to force section 96 on an otherwise coherent and satisfying rule of law argument — the same argument that works very well in Christie itself without any reference to that provision whatsoever.

\section{Conclusion}

Trial Lawyers is an unstable decision and ultimately reflects the instability in constitutional doctrine created by Imperial Tobacco's retreat into text. Imperial Tobacco inappropriately attempts to force written constraints on constitutional interpretation, and Trial Lawyers is caught between these constraints, on the one hand, and the unwritten principles that are the foundation of the Constitution, on the other. Under the architectural model, unwritten constitutional imperatives may be, but do not have to be, mediated by text. Such imperatives can flow directly from foundational principles, and indeed, when 
constitutional threats emerge, direct access to these underlying principles may be essential. The rule of law provides a clear and pragmatic basis on which to conclude that access to justice is a constitutional imperative, and neither requires, nor receives, any assistance from section 96 .

The architectural model of the Constitution outlined in the Judges Reference, the Secession Reference, and the earlier rulings discussed above is a significant judicial achievement. Ensuring future continuity with this rich body of constitutional law is imperative: "[O]bservance of and respect for [underlying] principles is essential to the ongoing process of constitutional development and evolution." "116 Imperial Tobacco should be set aside. 